\title{
Efeito da eletroterapia e cinesioterapia em um paciente com luxação de cotovelo
}

Fernanda Renata Covati

Marilia da Luz da Silva

Lilian Marin

Marcia Regina da Silva

CADERNO DE RESUMOS

Fisisenectus. Unochapecó Ano 1 - Edição especial - 2013

Vinícius Brandalise

Fernanda Renata Covati, Universidade Comunitária da Região de Chapecó (Unochapecó),

fercovatti@unochapeco.edu.br

\section{Resumo}

Introdução: As luxações de cotovelo ficam em segundo lugar entre as lesões de membros superiores, acometem ambos os gêneros. Resulta em deformidades osteomioarticulares visível, sendo fácil o diagnóstico e confirmado por exames de imagem. O tratamento é conservador por meio de trações e sua redução, seguida da imobilização do membro. Mobilizações precoces auxiliam na recuperação da mobilidade. Objetivos: Avaliar o ganho da amplitude de movimento e força muscular da articulação de ombro e cotovelo em um paciente com luxação de cotovelo. Metodologia: Avaliou-se paciente sexo masculino, 35 anos, com diagnóstico de luxação de cotovelo direito. Durante avaliação, identificou-se quadro álgico na região medial e lateral em epicôndilos de cotovelo, leve edema na região medial e lateral de cotovelo, diminuição da amplitude de movimento de flexão de cotovelo em $45^{\circ}$, extensão $10^{\circ}$, flexão de ombro $60^{\circ}$, abdução $40^{\circ}$, força muscular diminuída nos músculos deltoide anterior, médio, supraespinhoso, peitoral maior, coracobraquial, bíceps braquial e braquiorradial, leve retração de extensores longo e curto do carpo, moderada de bíceps e tríceps braquial e grave de braquiorradial. Diante os achados realizou-se com este paciente aplicação de aparelho ultrassom e turbilhão, liberação miofascial, massagem terapêutica, mobilização passiva e ativa, tração umerorradial e radioulnar proximal e distal, exercícios pendulares, alongamentos passivos, ativo-assitidos, ativos e plástico e fortalecimento em cadeia cinética fechada. Utilizando no tratamento tatames, aparelho US, turbilhão, creme terapêutico, tornozeleiras, faixas elásticas, polia e prancha de molas. Resultados: Após 13 atendimentos notou-se melhora significativa no terceiro atendimento, em que não relatava mais quadro álgico e no oitavo apresentava ganho da amplitude de movimento de flexão de cotovelo em $8^{\circ}$, extensão $4^{\circ}$ em ombro flexão $20^{\circ}$ e abdução $10^{\circ}$ e ausência de edema. Ao término dos atendimentos paciente apresentou ganho da amplitude de movimento de flexão de cotovelo em $12^{\circ}$, extensão $6^{\circ}$, flexão de ombro $40^{\circ}$ e abdução $60^{\circ}$, aumento da força muscular em $5^{\circ}$ nos flexores de ombro e flexores e extensores de cotovelo e diminuição de retração muscular para leve em bíceps, tríceps e braquiorradial. Considerações finais: A fisioterapia no tratamento pós-luxação de cotovelo foi eficaz para reabilitação do membro, propiciou ganho de amplitude de movimento e força muscular, eliminação do quadro álgico, edema e diminuição de retração recuperando a funcionalidade do membro.

\section{Palavras-chave}

Fisioterapia. Reabilitação. Luxação de cotovelo. Funcionalidade. 